\title{
Bank Performance and Board of Directors' Characteristics in the Context of Bangladeshi Islamic Banks
}

\author{
Mohammad Fahad NOOR \\ Senior Lecturer, Department of Finance, School of Business and Entrepreneurship \\ Independent University, Bangladesh \\ www.orcid.org/0000-0003-1435-9471 fahad@iub.edu.bd
}

\section{Zaima AHMED}

Lecturer, Department of Finance, School of Business and Entrepreneurship Independent University, Bangladesh www.orcid.org/0000-0002-8835-7148 zaima@iub.edu.bd

\section{Sajedul ISLAM}

Adjunct Lecturer, Department of Finance, School of Business and Entrepreneurship Independent University, Bangladesh www.orcid.org/0000-0002-3927-5277.

sajedul iub@yahoo.com

\begin{abstract}
This study focuses on investigating how bank performance is being impacted by BOD characteristics, Investment Account Holders (IAHS), and contribution to the society in the context of the Islamic Banking sector in Bangladesh for the period 2008-17. This study used only six Islamic banks' data in Bangladesh during 2008-17, and those banks are full-fledged Islamic banks. A generalized least squares (GLS) regression model has been used for this study. The empirical results show that ROA and ROE are significant, and the result shows Board size has an insignificant positive effect on ROA but the negative effect on ROE. That indicates the BODs are not selected based on their expertise and experience in Islamic banks. The result also shows that a smaller board can make quick decisions and monitoring performance effectively, and creating value. Besides that, the separation of CEO and chairman roles and the IAHs have no effect, while the chairman independence has a positive impact. As for the control variables, bank size positively influences bank performance, whereas leverage negatively affects performance. Zakah and gross domestic product produce no significant effect on bank performance.
\end{abstract}

Keywords: Corporate governance, Islamic banking, Bank performance, GLS regression model. 


\section{Introduction}

A proper banking system is required for any country's development, and it plays a crucial role in economic growth. Two types of commercial banks exist in an economy. One is conventional banks that do not follow any religious (Shariah) rules and principles, and another one Islamic banks based on Shariah. Conventional banks have either a one-tier or a two-tier system. In Germany, a traditional bank would be including the executive directors as the managing part within the two-tier system. It would have a separate supervisory board in the conventional banking system. The UK and the US typically have a one-tier system with the executive directors on the one hand and independent directors on the other hand. When it comes to Islamic finance, some edit components are included in the governance structure, and one very critical component is the Shariah board, certainly the internal review and audit department.

In Bangladesh, Islamic banking a phenomenon and is becoming more important. Islamic banks are famous for their transparency and good practices. Islamic banking arrived in Bangladesh in 1983, when some Saudi and Kuwaiti hedge funds decided to create an Islamic bank. This bank played a crucial role in turning an agricultural country into the textile powerhouse, and it is today. Today clothes make up 80\% of Bangladeshi exports, and Islami bank Bangladesh is the biggest bank in the country. Islamic banks follow the Shariah rules, and the majority of people are Muslim in this country and for this sentiment, most of the Muslim people willing to accept Islamic banks. Therefore, Islamic banks grow up very rapidly in this country. (Islam, 2010; Mohon, 2011; Mannan, 2010; Sarker, 2005 and BMB Islamic, 2011). In Bangladesh, there are 47 banks; among them, 8 are Islamic banks, and many conventional banks provide Islamic banking service of their branches (Yousuf et al., 2014; Khan, 2014 and Akbar, 2014).

Interbank Money Market (IIMM) is a remarkable infrastructure development for the Islamic banks in Bangladesh because, through the IIMM, all Islamic banks in Bangladesh can manage their fund. Vizcaino and Quadir (2012) studied Sukuk market is not developed yet in Bangladesh. The government needs to make necessary amendments and regulations to develop the Sukuk market in Bangladesh. Microfinance plays a vital role in this economy and revises the Grameen Bank's interest-based model. Several Islamic microfinance institutions have started their operations in the rural area of Bangladesh (BMB Islamic, 2011).

Islamic banks have an outstanding possibility to succeed in Bangladesh because Islamic banks have a solid financial position. Bangladesh bank publishes financial stability report, and this report shows that Islamic banks' income to total assets ratio (9.74\%) is higher than the industry average $(8.14 \%)$. The return on assets (ROA) of Islamic banks is higher than the whole banking industry (1.13 and 0.84 , respectively). Islamic banks' return on equity (ROE) was $16.81 \%$, and this financial ratio was also higher than the total banking sector (10.56\%). Besides that, Islamic banks have only a $3.9 \%$ non-performing portion of their total investment, but conventional banks have 10\% (Bangladesh Bank, 2013).

The framework of corporate governance in Islamic banks and conventional banks are not the same. Islamic banks usually take the minimum risk, and Islamic banks have Shariah supervisory board (SSB). This board is actually working as a second layer of independence governance mechanism. Most of the time, Shariah's supervisory board prevents them (BODs, top management) from taking the excessive risky project and an investment that will become harmful to this institution. Islamic banks follow Shariah rules and the principle, so their transparency level is very high as compared to conventional banks, and they used to disclose risk and financial position. Islamic banks have Shariah restrictions; for that reason, Islamic banks prefer to invest low risky projects (Hassan and Mollah, 2014). After the Enron scandal, corporate governance has become the most significant area of all institutions (Ahmed and Chapra, 2002). In 2000-01, the 
whole world observed the Turkish Ihlas finance house failure, and there were several reasons, and the most meaningful reason was the conspiracy of the board of directors (BoDs), management had taken an excessive risk, and auditors did not take it seriously (Grais and Pellegrini, 2006).

Islamic financial institutions have their own corporate governance framework, and it is based on Shariah, and this framework is clearly different from other financial firms. In this governance, BODs follow the advice of Shariah supervisory boards (SSB), alongside they work in accordance with Shariah principles and rules. In conventional banks, BODs ensure that they have proper knowledge of the banking industry, but the BODs of Islamic banks have required some additional qualifications, which is the members of BODs must have strong professional competence, and most importantly, they have to ethically sound. The primary criteria of members of BODs are the proper knowledge in Shariah regarding banking systems (Chapra, 2007). Rachdi and Ben Ameur (2011) examined that BODs usually use corporate governance mechanisms (internal \& external) to resolve agency problems and reduce agency cost. The BODs considered internal governance structure as the most effective mechanisms.

Bank's performance is affected by the management, and the management is the most crucial component of the internal corporate governance of a firm (Fama, 1980). The BODs in the banking industry are more important than other industries, confirmed by Pathan and Skully (2010). Every firm wants to improve its corporate value, and it is possible when agency problems and agency costs will be decreased. Haniffa and Hudaib (2006) examined that board attributes can decrease those issues. The most important components of Corporate governance are the BODs framework of a firm, and it shows how to improve performance by using recourses effectively (Gregory and Simms, 1999). Previous empirical findings could not assure that bank performance and BODs effectiveness is positively correlated. Previous studies face endogeneity problems, and the research sample set was biased and time duration. So, the main focus of this study is to overcome the previous limitations. Moreover, the performance of conventional banking may not be replicated in the context of Islamic banks of Bangladesh because of the different financial systems.

This study focuses on investigating how bank performance is being impacted by BOD characteristics, Investment Account Holders (IAHS), and contribution to the society in the context of the Islamic Banking sector in Bangladesh for the time period 2008-17.

\section{Literature review}

\section{Corporate governance in Islamic bank}

Corporate governance (CG) means applying best management practices, fulfillment of the law and ethical standards for effective management and distribution of wealth, and discharge of social responsibility for sustainable development of all stakeholders. Last few decades, Islamic banks (IBs) have grown up by their size and numbers in Bangladesh, and the competition between two different banking systems is intensified. The CG of Islamic banks and conventional banks are different. Islamic banks always follow the Shariah principle in every situation because the risk of Shariah incompliance can create an economic crisis. Islamic banks always characterized their investment accounts which complicate their governance system (Claessens, 2006).

The structure of Corporate Governance (CG) in Islamic financial institutions (IFIs) is different from other financial firms not only that its purpose is also different from other financial firms. Ahmed and Chapra (2002) examined Transparency and accountability are at the core of CG of IFIs that ensure fairness to all stakeholders upholding Islamic principles. According to Ibrahim (2006), Islamic Financial institutions (IFIs) follow the Shariah principle, so their main focus is not only profit but also other components. They are investigating transactional structure for finding 
elements derived from other than gains or profits would the first scrutiny under the CG of Shariah-compliant business.

Matoossi and Grassa (2014) examined the outcome of CG mechanisms on the banking industry, and they noticed there are many significant differences between Islamic banks and conventional banks. Some variables such as board fee, age of CEO, and CEO duality play a crucial role in Islamic banks, and those variables are also positively correlated with the performance of Islamic banks.

Basically, the past studies on CG of Islamic financial institutions (IFIs) did not examine the relationship between BODs characteristics and Islamic banks' performance except that of Matoossi and Grassa (2014). The main component of CG is the BODs structure, and banks' performance is influenced by this component (Bhagat and Bolton, 2008). The BODs ensure better monitoring which results in value maximization for the company, and the power of influence of BODs on the company performance depends on the attributes of this CG indicator. This study focuses on investigating how bank performance is being impacted by BOD characteristics, Investment Account Holders (IAHS), and contribution to society in the context of the Islamic Banking sector in Bangladesh.

\section{Hypotheses development}

\section{Board size and bank performance}

Usually, board size and bank performance are negatively correlated. According to Vance (1983), an odd number of individuals can successfully run a corporation, and three are overmuch. Numerous studies concluded that a corporation with too many boards of directors tends to perform poorly (Cheng, 2008; Singh and Davidson III, 2003). This is because, in large boards, proper coordination is very difficult to maintain. Moreover, information asymmetry is present on larger boards. Above all, on larger boards, it is very difficult to reach a consensus.

In the year 2011, a group of scholars (Grove et al., 2011) did a study on US commercial banks. Their study focuses on the post-financial crisis period. They found that board size and bank performance have a concave relationship. Similarly, another scholar (Pokrashenko, 2012) found a concave relationship between these two variables. According to this study, the optimal board size for a bank should be between 6 and 11 members.

On the contrary, some studies contradict previous findings. Arslan et al., (2010) concluded that board size has a positive relationship with corporations' share market performance. This study was conducted in Turkey, a period ranging from 1995 to 2006. Chang and Dutta (2012) supported this finding. This paper focuses on Canadian companies. According to their study, companies with large boards tend to pay a higher dividend. These companies usually do not venture into risky investments. Therefore, they are less prone to market risk. However, these findings could be biased if the research methodology does not control for endogeneity (Wintoki et al., 2009).

H1: The larger (lower) the board size, the greater (lesser) the influence of board members on the performance of the company.

\section{Board composition and bank performance}

In the past, the directorship was a very easy job - occasional meetings, lunch, and a few questions. However, this is not the practice now. Nowadays, the role and responsibilities of the director are very important. Directors have a significant influence on a firm's performance. Countless studies have examined the impact of board composition on performance, but the findings are mixed. According to Fama (1980), outside directors significantly increase the firm's value. Outside directors' act as a disciplinary device. They are very effective in monitoring and decision-making 
process. This is because they are independent of the management, and most importantly, they have their reputation at stake (Fama and Jensen, 1983).

Kutubi (2011) found a positive correlation between bank performance and board independence regarding the banking sector. She considered 28 banks Bangladeshi commercial banks in her study. Conversely, Prevost et al., (2012) found a negative relationship between outsiders in the board and the corporation's growth. This study focuses on the corporations of New Zealand. In addition to corporate growth, outside directors tend to hurt stock market performance (Arslan et al., 2010). In the financial crisis period, a bank with outside directors performed worse (Erkens et al., 2012).

Lastly, some studies found no statistically significant relationship between bank performance and board composition. Hermalin and Weisbach (1991) proved that there is no significant relationship between performance and board composition. Bhagat and Black (2001) and Johnson et al., (1996) found similar results. Adams and Mehran (2003) reinforced these findings and provided a rationale for these insignificant relationships. According to them, outside directors always try to comply with the regulatory requirements. These directors give priority to safety over shareholder value maximization.

H2: Bank performance is positively related to board composition.

\section{Investment account holder}

In Islamic Shariah Law, interest-bearing deposits are not allowed. Hence, Islamic banks raise money through an investment account, where profit and loss are shared. In the case of profit, the bank is entitled to an amount as remuneration. On the contrary, if there is a loss, then the banks receive nothing and do not share loss. In general, Islamic bank offers three types of investment account - investment account based on time (for instance, six months and one year), investment account based on notice (customer requires to give prior notice for withdrawal) and specific investment account (focused on specific investment). Each of these accounts complies with the mudaraba principle (Haron, 1996). In Bangladesh, Islamic banks are very efficient in the matter of loan recovery compared to conventional banks (Ahmad and Hassan, 2007).

H3: Islamic banks' performance is positively related to the proportion of IAH funds.

\section{Social contribution}

Islamic banks are more focused on social contribution than conventional banks, and they follow Islamic Shariah. We all know that Islam is based on five key practices known as pillars. Zakat and charity are at the center of addressing poverty in the Islamic economic system. Rich people are obliged to transfer a portion of their wealth to the poor, which is known as Zakat (Badawi et al., 1979). Since the early years of Islam, Zakat has been practicing as an automatic redistribution of the wealth of the rich amongst the poor (Shirazi, 1996). Every Muslim, according to their means, is required to give part of their income to help those in need. It is envisaged that Zakat would improve the quality of life and address the problem of inequality within the society, and generally best managed by Islamic Banks

H4: Islamic banks' performance is positively correlated to social contribution.

\section{Research method}

\section{Data and sample size}

For this study, data has been collected from Dhaka Stock Exchange (DSE). In Bangladesh, there are many commercial banks that have an Islamic bank wing, but we did not consider those banks in this because of simplicity. We considered only six banks which are full-fledged Islamic banks; 
those are Al-Arafah Islami Bank Ltd, ICB Islamic Bank Ltd, Islami Bank Bangladesh Ltd, Shahjalal Islami Bank Ltd, Social Islami Bank Ltd, and First Security Islami Bank Ltd. The time period of this study is $2008-17$ for the above-mentioned banks.

\section{Variable measurement}

This study had required bank performance measurement data, BODs attributes, and control variables collected from the annual report, and the GDP data were collected from the world bank website. This study also used two financial ratios for measuring a bank's performance, and these two ratios are considered the best for measuring performance (Sinkey, 2002) which are return on assets (ROA) and return on equity (ROE). Most of the previous studies used these two ratios to measure a bank's performance (Siddiqui, 2008; Sufian and Habibullah, 2009).

\section{Control variables}

This study had been used three more variables to control other possible outcomes of bank performance. These are called control variables, and the first control variable is bank size that is mostly used in previous studies of CG (Al-Saidi and Al-Shammari, 2013; Adusei, 2011; Haniffa and Hudaib, 2006). Islamic banks succeeded by the Shariah principles and rules, and one important principle is profit sharing. So, large Islamic banks always try to diversify their risk, and they usually offer their services and products at a lower price and higher profit. The second control variable is leverage (Al-Saidi and Al-Shammari, 2013; Adusei, 2011; Haniffa and Hudaib, 2006). Most of the time, Islamic banks used their internal resources first rather than outside funds for the investments. Islamic banks maintain more assets than debt, and that policy would improve their investments as well as performance (Bukair, 2013). Lastly, we used GDP as a control variable, and GDP is widely used in many previous studies of CG (Cosset et al., 2016; Gaeremynck et al., 2010). Usually, the relationship between GDP and financial sector activities is positive, and People with a higher income in Bangladesh intention to save money and save their money in banks. Therefore, Banks' funds have to increase, leading to more investment and thus better performance.

Table 1: Definition of the independent, dependent and control variables

\begin{tabular}{|c|c|}
\hline Variable & Definition \\
\hline \multicolumn{2}{|l|}{ Dependent Variable } \\
\hline Return on Asset (ROA) & Net income before tax and zakah/total asset \\
\hline Return on Equity & Net income before tax and zakah/total equity \\
\hline \multicolumn{2}{|l|}{ Independent Variable } \\
\hline \multicolumn{2}{|l|}{ BODs Characteristics } \\
\hline Board Size (BS) & The total number of directors on the board \\
\hline Board Composition (BC) & $\begin{array}{l}\text { The percentage of non-executive directors to total } \\
\text { number of directors on the board }\end{array}$ \\
\hline Investment Account Holders (IAH) & $\begin{array}{l}\text { Proportion of total investment account funds to } \\
\text { shareholders' equity }\end{array}$ \\
\hline Social Contribution (ZAK) & The total amount of zakah over total asset \\
\hline \multicolumn{2}{|l|}{ Control Variable } \\
\hline Bank Size (LTA) & The natural logarithm of total asset \\
\hline Leverage (LVG) & $\begin{array}{l}\text { Total liabilities without profit sharing investment } \\
\text { accounts (PSIA) over total asset }\end{array}$ \\
\hline Gross Domestic Product (GDP) & The annual change in GDP per capita \\
\hline
\end{tabular}




\section{Specification of the model}

Using panel data for this study that provide proper information on multiple statistical cases for many years. For this study, we did not use cross-sectional or time-series data because Panel data provide us more benefits in economic research in terms of increasing the levels of freedom and minimize the collinearity problems, with a purpose to improve the performance of the econometric estimates (Shah and Khan, 2007). In this study, both techniques (fixed and random effect) had been examined within the regression analysis. A Generalized Least Squares (GLS) regression model had been used in this study for both performance measures (ROA and ROE) to investigate the relationships between bank performance, independent variables, and control variables. This GLS model gives some redress like heterogeneity, which refers to unobserved variables. It also provides redress for the endogenetic time-invariant sources. This study used the GLS regression model, and this model is given below:

PERMit $=\beta 0+\beta 1 \mathrm{BS}+\beta 2 \mathrm{BC}+\beta 3 \mathrm{IAHs}+\beta 4 \mathrm{ZAK}+\beta 5 \mathrm{LTA}+\beta 6 \mathrm{LEV}+\beta 7 \mathrm{GDP}+\mu \mathrm{it}$

Where:

PERM = performance (using ROA and ROE);

$\mathrm{I}=$ cross section unit;

$\mathrm{T}=$ time series;

$\beta 0=$ intercept (has constant value);

$\beta 1$ to $\beta 7$ = the coefficients' scope;

$\mathrm{BS}=$ board size;

$\mathrm{BC}=$ board composition

$\mathrm{IAH}=$ investment account holder

$\mathrm{ZAK}=$ Zakah

LTA = bank size

LEV $=$ leverage

$\mathrm{GDP}=$ gross domestic product per capita and

$\mu \mathrm{it}=$ error term

\section{Empirical findings}

\section{Descriptive statistics}

In this study, we used both parametric and non-parametric tests. The performance measure variables (ROA and ROE), four independent variables, and three control variables have been shown in table 2.

Table 2 shows that the mean value of ROA was 0.013266 and ROE was 0.141817 . This studied mean value is more accurate than other previous studies. Bukair (2013) shows that in his paper, the mean value of ROA and ROE was -0.30 and -0.072 , respectively, and Bukair and Rahman (2015) studied shows the mean value of the same ratio were -0.023 and -0.037 , respectively. The one important noticeable thing is that both studies showed a negative result, and it's maybe due to the 2007 financial crisis.

Table 2 also shows that the mean value of board size is 15.13 that means the board size of Islamic banks in Bangladesh consists of a minimum of 15 executive directors. The number of directors on 
the board was 8.8, as reported in a study by Bukair and Rahman (2015) for Islamic banks in GCC countries. Al-Saidi and Al-Shammari (2013) studied to show the board size of the banks in Kuwait is 8.28. In the CG for IFIs, the ideal board size should not be less than seven persons recommended by Hawkamah (2011). The mean value of Board Composition (BC) is 0.9170 , and this result shows that more than 90 percent of directors were NEDs. This result is quite similar to 91.23 percent, as reported in a study by Bukair and Rahman (2015) for Islamic banks in GCC countries. Al-Saidi and Al-Shammari (2013) studied show that 94 percent of directors were NEDs in Kuwaiti banks.

The mean value of IAH is about 9.53 percent which implies that Islami banks in Bangladesh are less dependent on the investment account equity in funding their operations than shareholder's equity. This reflects investors have less confidence in Islami Banks. The last independent variable is Zakah, and the mean value of social contribution (ZAK) is 0.0495 . The previous study by Bukair and Rahman (2015) shows the amount of Zakah was 0.0079 for Islamic banks in GCC countries. This result indicates that all Islamic banks in Bangladesh contribute less than 1 percent of Zakah to the community.

Now we focus on the control variables, the mean value of bank size is 5.03 million, and leverage is 29.021, which are significantly lower than previous studies like Bukair and Rahman (2015), and Bukair (2013). Finally, the GDP per capita shows the mean value is 0.1063 , and the result indicates the country's economic development.

\section{Table 2: Descriptive statistics of dependent, explanatory and control variables}

\begin{tabular}{|c|c|c|c|c|c|c|c|c|c|}
\hline & BS & $B C$ & IAH & ZAK & $S$ & LV & GDP & ROA & ROE \\
\hline Mean & 15.13559 & 0.917019 & 9.537305 & 0.049563 & 5.032857 & 29.02132 & 0.106314 & 0.013266 & 0.141817 \\
\hline Median & 16.00000 & 0.933300 & 9.375000 & 0.000145 & 5.113736 & 0.928099 & 0.109531 & 0.012400 & 0.128200 \\
\hline Maximum & 22.00000 & 0.954500 & 23.22300 & 0.737500 & 5.954223 & 1653.834 & 0.137295 & 0.610000 & 0.464500 \\
\hline Minimum & 5.000000 & 0.800000 & 0.845000 & 0.000000 & 4.071338 & 0.086964 & 0.023256 & -0.109200 & 0.014400 \\
\hline Std. Dev. & 4.621754 & 0.038120 & 5.062590 & 0.184589 & 0.510431 & 215.1799 & 0.030237 & 0.084206 & 0.076450 \\
\hline Skewness & -0.567198 & -1.277274 & 0.297264 & 3.439038 & -0.341736 & 7.484448 & -1.972878 & 6.042074 & 1.420958 \\
\hline Kurtosis & 2.176931 & 4.032344 & 3.166986 & 12.82868 & 2.253508 & 57.01706 & 6.170197 & 44.41438 & 6.992876 \\
\hline Jarque-Bera & 4.828897 & 18.66231 & 0.937478 & 353.7807 & 2.518283 & 7723.863 & 62.98037 & 4575.394 & 59.04806 \\
\hline Probability & 0.089417 & 0.000089 & 0.625791 & 0.000000 & 0.283898 & 0.000000 & 0.000000 & 0.000000 & 0.000000 \\
\hline Sum & 893.0000 & 54.10410 & 562.7010 & 2.924241 & 296.9386 & 1712.258 & 6.272534 & 0.782700 & 8.367200 \\
\hline Sum Sq. Dev. & 1238.915 & 0.084280 & 1486.529 & 1.976234 & 15.11133 & 2685538. & 0.053029 & 0.411259 & 0.338988 \\
\hline Observations & 59 & 59 & 59 & 59 & 59 & 59 & 59 & 59 & 59 \\
\hline
\end{tabular}

Table 3 Illustrates that the correlation between the independent, dependent, and control variables. According to Gujarati (2004), multicollinearity is considered a severe problem when the correlation between dependent and independent variables exceeds 0.80 . There is no significant relationship between dependent and independent variables. The dependent variable ROE has a strong positive correlation with board size with a value of 0.82 . There is a strong positive correlation exists between BS and BC. On the other hand, Zakah and ROA had a very weak negative correlation with a value of -0.0246 . Control variable leverage had a very weak negative correlation with dependent and explanatory variables. 
Table 3: Correlation matrix

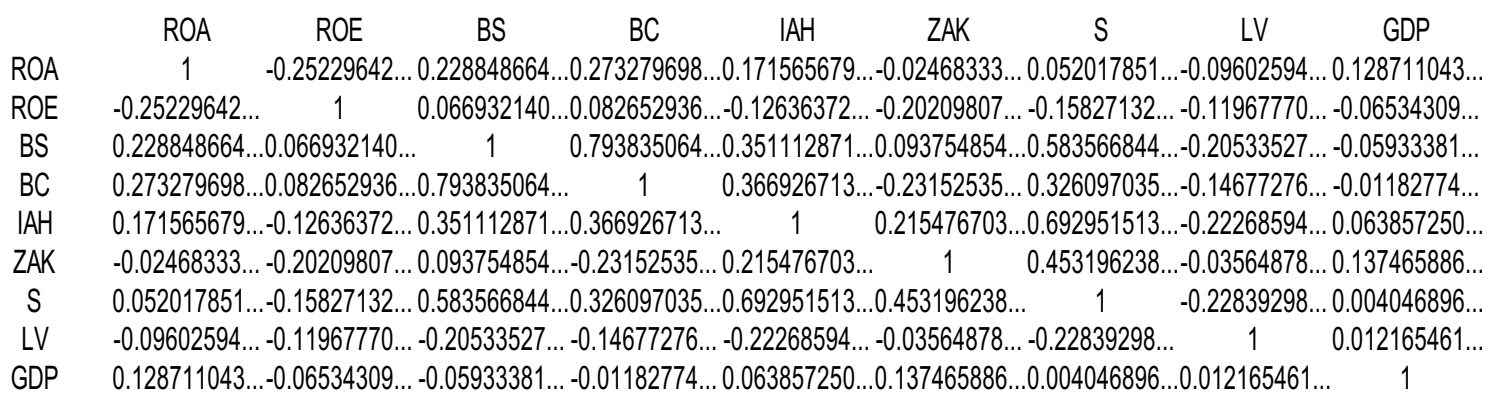

\section{GLS Model Findings}

This study used the GLS model, and the result of this model has shown in Tables 4 and 5 . This study used two performance measures ratios: ROA and ROE, and the result of both variables is significant at the less than 5 percent level. The result of R squared for ROA is 0.2198 and ROE is o.4351, and this result indicates around 22 and 44 percent variance in both measures of performance is interpreted by four independent variables and three control variables.

Table 4 shows that Board Size (BS) has an insignificant positive effect on ROA. On the other hand, table 5 shows that Board Size (BS) has an insignificant negative effect on ROE. So, H1 is rejected.

Board Size (BS) has an insignificant positive effect on ROA and an insignificant negative effect on ROE. Thus, $\mathrm{H} 1$ is rejected. The negative sign indicates that the directors in Islamic banks' boards are not selected based on their expertise and experience, but more often for fulfilling the requirements of CG codes. The result also matches with Mamun, Noor, and Musa (2016) for Bangladeshi banks'. The results of both measures imply that a smaller board makes quicker decisions and plays an effective role in monitoring performance and creating value for Bangladesh Islami Banks'.

The ratio of NEDs on the board (BC) has an insignificant positive effect on performance, leading to rejecting H2. Besides, this finding contradicts previous studies by Al-Saidi and Al-Shammari (2013). None of the hypotheses can be accepted based on the given regression result.

Table 4: ROA GLS regression output

Dependent Variable: ROA

\begin{tabular}{crcrr}
\hline \hline Variable & Coefficient & Std. Error & t-Statistic & Prob. \\
& & & & \\
\hline \hline ROE & -0.349371 & 0.144914 & -2.410880 & 0.0196 \\
BS & 0.006269 & 0.005210 & 1.203221 & 0.2346 \\
BC & 0.135406 & 0.586750 & 0.230773 & 0.8184 \\
IAH & 0.004085 & 0.003269 & 1.249724 & 0.2172 \\
ZAK & 0.004297 & 0.075303 & 0.057067 & 0.9547 \\
S & -0.068585 & 0.040374 & -1.698752 & 0.0956 \\
LV & $-3.74 \mathrm{E}-05$ & $5.13 \mathrm{E}-05$ & -0.729228 & 0.4693 \\
GDP & 0.320244 & 0.356960 & 0.897142 & 0.3739 \\
C & 0.116801 & 0.546822 & 0.213600 & 0.8317 \\
& & & & \\
\hline \hline R-squared & 0.219788 & Mean dependent var & & 0.013266 \\
Adjusted R-squared & 0.094954 & S.D. dependent var & & 0.084206
\end{tabular}




$\begin{array}{lllr}\text { S.E. of regression } & 0.080109 & \text { Akaike info criterion } & -2.071298 \\ \text { Sum squared resid } & 0.320869 & \text { Schwarz criterion } & -1.754385 \\ \text { Log likelihood } & 70.10328 & \text { Hannan-Quinn criter. } & -1.947588 \\ \text { F-statistic } & 1.760640 & \text { Durbin-Watson stat } & 1.209216 \\ \text { Prob(F-statistic) } & 0.107557 & & \end{array}$

Table 05: ROE GLS regression output

Dependent Variable: ROE

\begin{tabular}{crrrr}
\hline \hline Variable & Coefficient & Std. Error & t-Statistic & Prob. \\
& & & & \\
ROA & -0.215846 & 0.147271 & -1.465639 & 0.1497 \\
BS & -0.002106 & 0.006426 & -0.327655 & 0.7447 \\
BC & 0.226262 & 0.638855 & 0.354168 & 0.7249 \\
IAH & -0.011050 & 0.006098 & -1.812008 & 0.0767 \\
ZAK & 0.036909 & 0.070668 & 0.522290 & 0.6040 \\
S & -0.079434 & 0.053652 & -1.480543 & 0.1457 \\
LV & $-1.89 \mathrm{E}-05$ & $4.67 \mathrm{E}-05$ & -0.405082 & 0.6873 \\
GDP & 0.402672 & 0.326117 & 1.234748 & 0.2233 \\
C & 0.329338 & 0.583867 & 0.564064 & 0.5755 \\
& & & & \\
\hline \hline
\end{tabular}

Effects Specification

Cross-section fixed (dummy variables)

\begin{tabular}{lllr}
\hline \hline R-squared & 0.435128 & Mean dependent var & 0.013266 \\
Adjusted R-squared & 0.271943 & S.D. dependent var & 0.084206 \\
S.E. of regression & 0.071850 & Akaike info criterion & -2.224773 \\
Sum squared resid & 0.232309 & Schwarz criterion & -1.731798 \\
Log likelihood & 79.63080 & Hannan-Quinn criter. & -2.032335 \\
F-statistic & 2.666466 & Durbin-Watson stat & 1.455156 \\
Prob(F-statistic) & 0.007417 & & \\
\hline
\end{tabular}

\section{Conclusion}

The purpose of the study is to investigate the impact of BODs mechanisms (Board size, the composition of the board, chairman independence), Investment Account Holders (IAHs), and the social contribution on the bank performance during the time of 2008-17 and the sample is 6 Islamic banks in Bangladesh. This study used The GLS model for testing the relationship between independent and dependent variables. This study shows that the performance of Islamic banks in Bangladesh is not dependent on BODs mechanisms, IAHs, and social contribution. The outcomes of this study fail to reject the hypothesis that the BODs mechanisms, IAHs, and social contribution can improve Islamic banks' performance. Most importantly, The shareholders of Islamic banks appointed Board members for better performance, but unfortunately, their 
knowledge was insufficient in the Shariah banking system. So, that was not affected on banking performance. According to Shariah principles and rules, A non-executive chairman has the capability to cordially practice BODs mechanisms and ensuring all the stakeholders' interests have the ability to realize the economic and social objective. Also, the outcomes have shown that the management protects only shareholders' interests, not the other investors such as Investment Account Holders (IAHs).

The findings of this study will help the policymakers and regulatory body of Islamic banks to improve their strategies that will help those banks for better performance and produce better value. The policymakers in Islamic banks are the key component to enhance their performance. The policymakers should evaluate board size regularly and improve the board activities, which will give the better performance.

Although this study has some limitations, it creates an opportunity for future research. This study discovered a significant part of the variation in bank performance by the GLS model, but due to insufficient data, the significant factors of this model are unexplained.

For example, further research may use other mechanisms of corporate governance (CG), including the remuneration committee as well as the nominating committee, top five largest shareholders, and managerial shareholding. Under conventional banking, these factors have been found dominating theoretically and empirically in CG studies. Perhaps, some of these factors may be appropriate to Islamic banks. Next, for the short, mid, and long term performance of Islamic banks,' there is a need to study the impact of CG changes. Finally, the sample is limited to Bangladeshi Islamic banks only. Future research may extend the sample to all South Asian, Middle East, and Western countries. A comparative study can be conducted between Islamic banks operating in Islamic countries and South Asian countries.

\section{References}

Adams, R. B., \& Mehran, H. (2003). Is corporate governance different for bank holding companies?. Available at SSRN 387561.

Adusei, M. (2011). Board structure and bank performance in Ghana. Journal of Money, Investment and Banking, 19(1), 72-84.

Ahmad, A. U. F., \& Hassan, M. K. (2007). Regulation and performance of Islamic banking in Bangladesh. Thunderbird International Business Review, 49(2), 251-277.

Ahmed, H., \& Chapra, M. U. (2002). Corporate Governance in Islamic Financial Institution (Occasional Paper) (No. 93). The Islamic Research and Teaching Institute (IRTI).

Akbar, C. S. (2014). Analysing the Islamic banking framework in Bangladesh. New Age, 9.

Al-Saidi, M., \& Al-Shammari, B. (2013). Board composition and bank performance in Kuwait: an empirical study. Managerial Auditing Journal.

Arslan, O., Karan, M. B., \& Eksi, C. (2010). Board structure and corporate performance. Managing Global Transitions, 8(1), 3.

Badawi, M. Z., Zaki, M. A., \& ul Amwal, K. (1979). Zakat and Social Justice. Islamic Council of Europe, London.

Bank, B. (2013). Financial stability report 2012. Retrieved May, 18, 2015.

Bhagat, S., \& Black, B. (2001). The non-correlation between board independence and long-term 
firm performance. J. CorP. 1., 27, 231.

Bhagat, S., \& Bolton, B. (2008). Corporate governance and firm performance. Journal of Corporate Finance, 14(3), 257-273.

Bukair, A. A. (2013). Influencing of Specific-Firm characteristics on Islamic banks' profitability; Evidence from gulf cooperation council countries. American Academic \& Scholarly Research Journal, 5(4), 110.

Bukair, A. A., \& Rahman, A. A. (2015). Bank performance and board of directors attributes by Islamic banks. International Journal of Islamic and Middle Eastern Finance and Management.

Chang, B., \& Dutta, S. (2012). Dividends and corporate governance: Canadian evidence. IUP Journal of Applied Finance, 18(4), 5.

Chapra, M. U. (2007). 21 Challenges facing the Islamic financial industry. Handbook of Islamic banking, 325.

Cheng, S. (2008). Board size and the variability of corporate performance. Journal Of Financial Economics, 87(1), 157-176.

Claessens, S. (2006). Corporate Governance of Islamic Banks: Why is Important, How is it Special and What does this Imply. The World Bank Financial Sector Network.

Cosset, J. C., Somé, H. Y., \& Valéry, P. (2016). Does competition matter for corporate governance? The role of country characteristics. Journal Of Financial And Quantitative Analysis, 1231-1267.

Erkens, D. H., Hung, M., \& Matos, P. (2012). Corporate governance in the 2007-2008 financial crisis: Evidence from financial institutions worldwide. Journal Of Corporate Finance, 18(2), 389-411.

Fama, E. F. (1980). Agency problems and the theory of the firm. Journal Of Political Economy, 88(2), 288-307.

Fama, E. F., \& Jensen, M. C. (1983). Agency problems and residual claims. The journal of law and Economics, 26(2), 327-349.

FCMA, S. A., Noor, M. F., \& Musa, S. (2016). The impact of internal corporate governance on firm performance: empirical evidence from Bangladesh, Malaysia \& Singapore. Independent Business Review, 9, 1.

Gaeremynck, A., Sercu, P., \& Renders, A. (2010). Corporate-governance ratings and company performance: A cross-European study. Corporate Governance: An International Review, 18(2), 87-106.

Grais, W., \& Pellegrini, M. (2006). Corporate governance and Shariah compliance in institutions offering Islamic financial services. The World Bank.

Gregory, H. J., \& Simms, M. E. (1999). Corporate Governance: What It Is and Why It Matters The 9th International Anti-Corruption Conference (IACC) papers. Durban, South Africa, 9-15.

Grove, H., Patelli, L., Victoravich, L. M., \& Xu, P. (2011). Corporate governance and performance in the wake of the financial crisis: Evidence from US commercial banks. Corporate Governance: An International Review, 19(5), 418-436.

Gujarati, D. (2004). Basic Econometrics.(4 th edtn) The McGraw- Hill Companies. 
Haniffa, R., \& Hudaib, M. (2006). Corporate governance structure and performance of Malaysian listed companies. Journal of Business Finance \& Accounting, 33(7-8), 1034-1062.

Haron, S. (1996). The effects of management policy on the performance of Islamic banks. Asia Pacific Journal of Management, 13(2), 63-76.

Hassan, M. K., \& Mollah, S. (2014, September). Corporate Governance, Risk Taking and Firm Performance of Islamic Banks during Global Financial Crisis. In Finance and Development in Islamic Economies Conference (pp. 1-36).

Hermalin, B. E., \& Weisbach, M. S. (1991). The effects of board composition and direct incentives on firm performance. Financial Management, 101-112.

Ibrahim, A. A. (2006). Convergence of corporate governance and Islamic financial services industry: toward Islamic financial services securities market.

Islam, M. N. (2010). Bangladeshe Islami bank protishthar andoloner itihash. Amar Desh, 21.

Islamic, B. M. B. (2011). Global Islamic finance report (GIFR) 2011. London: BMB Islamic UK Limited.

Johnson, J. L., Daily, C. M., \& Ellstrand, A. E. (1996). Boards of directors: A review and research agenda. Journal of Management, 22(3), 409-438.

Khan, M. T. A. (2014). Huge demand for Islamic banking in Bangladesh. Islamic Finance News, 27.

Kutubi, S. S. (2011). Board of director's size, independence and performance: An analysis of private commercial banks in Bangladeshi. World Journal Of Social Sciences, 1(4), 159-178.

Mannan, M. A. (2010). Islami Bank Babostha. Dhaka: Central Shariah Board for Islamic Banks of Bangladesh.

Matoossi, H., \& Grassa, R. (2014). Is corporate governance different for Islamic banks?. International Journal of Business Governance and Ethics, 9(1), 27-51.

Mohon, I. K. (2011). Islami Orthoniti O Banking.

Pathan, S., \& Skully, M. (2010). Endogenously structured boards of directors in banks. Journal of Banking \& Finance, 34(7), 1590-1606.

Pokrashenko, P. (2012). Cost efficiency of Russian banks: the impact of board of directors and executive group (No. 12/02e). EERC Research Network, Russia and CIS.

Prevost, A. K., Rao, R. P., \& Hossain, M. (2002). Determinants of board composition in New Zealand: a simultaneous equations approach. Journal of empirical finance, 9(4), 373-397.

Rachdi, H., \& Ameur, I. G. B. (2011). Board characteristics, performance and risk taking behaviour in Tunisian banks. International Journal of Business and Management, 6(6), 88-97.

Saidi, N. (2013). Policy Brief on Corporate Governance for Islamic Banks and Financial Institutions in the Middle East and North Africa Region. Hawkamah: The Institute for Corporate Governance. Available at http://www. scief. es/publications/publication16. pdf Accessed, 27.

Sarker, A. A. (2005). Islamic banking in Bangladesh: Achievements and challenges. Journal of Islamic Economics and Finance, 1(1), 45-59. 
Shah, A., \& Khan, S. (2007). Determinants of capital structure: Evidence from Pakistani panel data. International review of business research papers, 3(4), 265-282.

Shirazi, N. S. (1996). Targeting, coverage and contribution of zakat to households' income: the case of Pakistan. Journal of economic cooperation among Islamic countries, 17(3-4), 165-186.

Siddiqui, A. (2008). Financial contracts, risk and performance of Islamic banking. Managerial finance.

Singh, M., \& Davidson III, W. N. (2003). Agency costs, ownership structure and corporate governance mechanisms. Journal of Banking \& Finance, 27(5), 793-816.

Sinkey, J. F. (2002). Commercial bank financial management.

Sufian, F., \& Habibullah, M. S. (2009). Bank specific and macroeconomic determinants of bank profitability: Empirical evidence from the China banking sector. Frontiers of Economics in China, 4(2), 274-291.

Vance, S. C., \& Kernan, S. (1983). Corporate leadership: Boards, directors, and strategy. New York: McGraw-Hill.

Vizcaino, B., \& Quadir, S. (2012). Bangladesh launches Islamic interbank money market.

Wintoki, J., Linck, J., \& Netter, J. (2009). Endogeneity and the Dynamics of Corporate Governance. European Summer Symposium in Financial Markets, CEPR.

Yousuf, S., Islam, M. A., \& Islam, M. R. (2014). Islamic banking scenario of Bangladesh. Journal of Islamic Banking and Finance, 2(1), 23-29. 